\title{
ANALISIS 4P (PRODUCT, PRICE, PLACE, DAN PROMOTION) DALAM PENG AMBILAN KEPUTUSAN CALON MAHASISWA MEMILIH PERGURUAN TINGGI
}

\author{
Rosita Yuniati, Patria Mukti \\ Fakultas Psikologi Universitas Setia Budi Surakarta \\ rosita_yuniati@setiabudi.ac.id
}

\begin{abstract}
Abstrak
Penelitian ini bertujuan untuk mengetahui (1) faktor-faktor yang mempengaruhi pengambilan keputusan calon mahasiswa dalam memilih Perguruan Tinggi, (2) faktor dominan yang mempengaruhi keputusan calon mahasiswa dalam memilih Perguruan Tinggi. Responden penelitian ini terdiri dari siswa-siswa SMU dari beberapa SMU di Kota Solo sebanyak 254 siswa dan mahasiswa baru Universitas Setia Budi sebanyak 247, sehingga total responden adalah 501 orang. Hasil penelitian menunjukkan bahwa terdapat tiga faktor yang mempengaruhi pengambilan keputusan dalam memilih Perguruan Tinggi yaitu (1) faktor akademik, yang terdiri dari keringanan biaya, biaya pendidikan, status akreditasi, kurikulum, dosen, karyawan dan kemudahan mencari pekerjaan (2) faktor sarana dan prasarana yaitu: kondisi gedung, kelengkapan fasilitas, kondisi lingkungan kampus dan (3) faktor pendukung.yang terdiri dari overseas studium generale dan dukungan keluarga.
\end{abstract}

Kata Kunci : Faktor 4P, Pengambilan Keputusan Calon Mahasiswa.

\begin{abstract}
This study aims to determine (1) the faktors that influence the decision of prospective students in choosing University, (2) dominant faktors that influence the decision of prospective students in choosing University. This research was conducted to 254 students in several senior high schools in Solo and 247 students in Setia Budi University, so total respondents are 501 respondents. to know faktors influencing decision of prospective student in choosing University and dominant faktor in making decision to choose University. The result of research indicate that there are three faktors that influence decision making in choosing University: (1) academic faktor, consisting of cost relief, education cost, accreditation status, curriculum, lecturer, employee and ease of looking for work (2) facility and facility faktor namely: the condition of the building, the completeness of the facility, the condition of the campus environment and (3) the supporting faktor.which consists of overseas studium generale and family support.
\end{abstract}

Keywords: Faktor 4P, Student Candidate Decision Making 


\section{PENDAHULUAN}

Pendidikan memiliki peran penting dalam menghasilkan sumberdaya manusia yang handal. Penyedia jasa pendidikan memiliki kewajiban untuk menciptakan manusia berkualitas melalui suatu proses pendidikan yang efektif. Secara umum penyedia jasa pendidikan di Indonesia terdiri dari dua macam, yaitu jasa pendidikan yang diselenggarakan oleh pemerintah dan oleh badan/perorangan sering disebut sebagai swasta. Dalam sistem pendidikan nasional, jenjang pendidikan yang akan dilalui peserta didik adalah jenjang pendidikan dasar, menengah (pertama dan atas) serta pendidikan tinggi (Tampubolon, 2001). Dalam HELTS 2003-2010 pengembangan pendidikan tinggi diarahkan pada tiga isu utama yaitu peningkatan daya saing bangsa, otonomi pengelolaan pendidikan dan peningkatan kesehatan organisasi penyelenggara perguruan tinggi. Pemerintah telah beruapa untuk meningkatan mutu perguruan tinggi melalui penetapan Sistem Penjaminan mutu Perguruan Tinggi (SPMPT) dalam menentukan standar mutu. (Mulyatini dkk, 2013)

Tujuan pendidikan tinggi yaitu melaksanakan Tri Dharma Perguruan Tinggi, yaitu : 1) pendidikan dan pengajaran; 2) penelitian dan 3) pengabdian kepada masyarakat. Kegiatan utama perguruan tinggi adalah memberikan jasa pendidikan kepada mahasiswa. Menurut Tjiptono (1998) jasa adalah setiap tindakan atau perbuatan yang dapat ditawarkan oleh suatu pihak kepada pihak lain, yang pada dasarnya bersifat intangible (tidak berwujud fisik) dan tidak menghasilkan kepemilikan sesuatu. Produksi jasa bisa berhubungan dengan produk fisik atau tidak. Jasa pendidikan adalah pelayanan yang diberikan kepada para mahasiswa untuk memenuhi kebutuhan mereka. Oleh karena itu mutu/kualitas jasa pendidikan haruslah sesuai dengan atau melebihi kebutuhan mahasiswa.

Banyaknya Perguruan Tinggi di Indonesia membuat masing-masing Perguruan Tinggi berkompetisi satu sama lain dalam menjaring mahasiswa. Sebuah perguruan tinggi harus terlihat lebih "menonjol" dibandingkan perguruan tinggi lain untuk menarik minat mahasiswa Semakin meningkatnya tahun, semakin meningkat pula kekritisan mahasiswa maupun calon mahasiswa terhadap mutu Perguruan Tinggi. Calon mahasiswa tentu akan mencari Perguruan Tinggi yang berkualitas serta mampu memberikan garansi masa depan yang lebih baik. Bagi mahasiswa, Perguruan Tinggi juga dituntut untuk tetap menjaga kualitas serta mutu pendidikan demi tercapainya tujuan Tri Dharma Perguruan Tinggi dengan baik. Perguruan Tinggi diharapkan segera menyadari segala macam tuntutan tersebut agar mampu bersaing dengan perguruan tinggi lainnya.

Berdasarkan latar belakang tersebut, maka peneliti tertarik untuk mengidentifikasi faktor-faktor apa saja yang mempengaruhi pengambilan keputusan calon mahasiswa dalam memilih Perguruan Tinggi, dan faktor dominan yang mempengaruhi keputusan calon mahasiswa dalam memilih Perguruan Tinggi. 


\section{METODE PENELITIAN}

Metode penelitian yang digunakan adalah penelitian eksplanasi dengan pendekatan kuantitatif. Penelitian eksplanasi bertujuan untuk meneliti sejauhmana variable yang satu memiliki hubungan sebab akibat dengan variable lain. Penelitian ini bertujuan untuk mengetahui faktor-faktor yang mempengaruhi pengambilan keputusan dalam memilih Perguruan Tinggi dan faktor mana yang paling dominan. Analisis yang digunakan adalah analisis faktor.

Variabel Penelitian yang akan diteliti dalam penelitian ini adalah faktor -faktor 4P mempengaruhi Pengambilan keputusan memilih Perguruan Tinggi. Hal ini sejalan dengan yang dikemukakan oleh Pearce dan Robinson (dalam Kotler, 2001) yaitu kunci dalam pemasaran strategi fungsional ada empat komponen komponen strategi fungsional pemasaran (marketing mix strategy) 4P yaitu sebagai berikut yaitu:

(1) Produk: Produk adalah barang atau jasa yang dijual belikan. Dalam marketing produk adalah apapun yang ditawarkan ke sebuah pasar dan bias memuaskan keinginan atau kebutuhan. Konsep keseluruham atas obyek atau proses yang memberikan berbagai nilai bagi mahasiswa. Dalam penelitian ini produk terfokus pada produk jasa perguruan tinggi swasta. Sub produk jasa pendidikan yang dapat mempengaruhi mahasiswa swasta dalam keputusn memilih Perguruan Tinggi adalah: a. kurikulum (X1); b. citra atau image (X2); c. status akreditasi (X3), dosen (X4), dan karyawan (X5)

(2) Harga: Harga adalah suatu nilai tukar produk barang maupun jasa yang dinyatakan dalam satuan moneter. Harga merupakan salah penentu keberhasilan suatu perusahan karena harga menentukan seberapa besar keuntungan yang akan diperoleh dari penjualan produknya baik berupa barang maupun jasa, merupakan nilai jasa yang ditetapkan oleh perguruan tinggi swasta dalam bentuk jumlah nominal yang ditawarkan. Aspek yang termasuk dalam faktor harga yang mempengaruhi mahasiswa dalam pemilihan perguruan tinggi swasta adalah : Biaya pendidikan (X6), Potongan biaya pendidikan (X7), Beasiswa $P(X 8)$.

(3) Place: bidang atau wadah yang digunakan sebagai tempat usaha yang akan kita jalankan nantinya. Lokasi dalam jasa merupakan gabungan antara lokasi dan keputusan atas saluran distribusi, dalam hal ini berhubungan dengan bagaimana cara penyampaian jasa kepada konsumen dan dimana lokasi yang strategis. Aspek yang mempengaruhi mahasiswa memiih perguruan tinggi termasuk dalam faktor harga antara lain: kelengkapan fasilitas kampus (X9), kondisi lingkungan kampus (X10), kondisi gedung kuliah ( X11)

(4) Promotion: Promosi yaitu kegiatan-kegiatan yang mengkomunikasikan manfaat produk yang ditawarkan dan yang bmempersuasi para pelanggan untuk membelinya, yaitu pengiklanan, penjualan tatap muka, promosi penjualan, publisitas. Aspek-aspek promotion adalah keluarga ( X12), teman (X13), keberhasilan alumni (X14), kemudahan memperoleh pekerjaan (X15), keberadaan teman-teman kuliah ( X16), overseas stadium general (X17). 
Pemilihan Perguruan tinggi dapat dilihat melalui 3 proses keputusan (Hotler, 1987, Jackson, 1985, dalam Meilyaningsih, E., 2014) . Tahap pertama adalah pembentukan aspirasi kampus, dimana calon mahasiswa mengembangkan perhatian mereka untuk melanjutkan pendidikan setelah SMU, setelah aspirasi terbentuk, calon mahasiswa akan memasuki tahap kedua yaitu mencari dan mendaftar di kampus. Pada tahap ini mahasiswa mulai mencari informasi yang berkenaan dengan atribut perguruan tinggu dan akan berakhir dengan calon mahasiswa mendaftar ke perguruan tinggi tertentu. Tahap ketiga yaitu mahasiswa megikuti seleksi dan kehadiran aktual, tahap ini akan berakhir sampai dengan kehadiran final dan keputusan untuk mendaftar di kampus tersebut. Dalam penelitian ini tidak semua proses pengambilan keputusan dijadikan sub variabel, karena pada tahap 5 (lima) tidak bisa dilakukan sekarang. Sehingga untuk variabel $Y$ (pengambilan keputusan) hanya 4 (empat) tahap, yaitu : pengenalan kebutuhan, pencarian informasi, evaluasi alternatif dan pengambilan keputusan.

Menurut Lin (1997, dalam Iranita 2012) alasan mahasiswa untuk memilih sebuah universitas adalah; lembaga berkualitas, pendidikan yang ditawarkan, peluang karir, reputasi perguruan tinggi, kesempatan untuk traineeships, kualifikasi fakultas, standar akademik, fasilitas modern yang tersedia, dan penekanan kurikulum. Sedangkan senada dengan Lin, Sander (1986, dalam Iranita 2012) mengatakan alasan mahasiswa memilih universitas penelitiannya adalah: kesempatan bekerja setelah lulus, berbagai kursus, biaya kehadiran, reputasi perguruan tinggi, kemudahan lokasi.

Pengambilan keputusan mahasiswa memilih perguruan tinggi adalah pengambilan pilihan yang dilakukan mahasiswa atau calon mahasiswa baru dalam memilih perguruan tinggi. Subjek dalam penelitian ini menggunakan mahasiswa baru Universitas Setia Budi dari berbagai Fakultas dan siswa SMU dari beberapa SMU di Solo dengan total responden adalah 501 orang.

Teknik pengambilan data sampling menggunakan teknik purpossive random sampling. Alasan peneliti menentukan karakteristik diatas berdasarkan tujuan dari penelitian yaitu mengetahui faktor-faktor yang yang mempengaruhi mahasiswa dan calon mahasiswa dalam mengambil keputusan memilih Perguruan Tinggi, sehingga peneliti memilih subjek penelitian calon mahasiswa dalam hal ini siswa SMU kelas XII yang akan melanjutkan ke perguruan tinggi dan mahasiswa baru di lingkungan Universitas Setia Budi.

\section{HASIL PENELITIAN}

Berdasarkan hasil penelitian didapatkan hasil variable-variabel independen dapat dikelompokkan ke dalam satu atau beberapa faktor. Jadi dari 13 variabel yang mempengaruhi calon memilih perguruan tinggi dapat disederhanakan ke dalam satu atau beberapa faktor. 
Adapun urutan faktor yang mempengaruhi mahasiswa dan calon mahasiswa dalam mengambil keputusan memilih Perguruan Tinggi adalah sebagai berikut :

1. Kondisi lingkungan kampus dengan prosentase $80,1 \%$

2. Kelengkapan fasilitas dengan prosentase $78,1 \%$

3. Kondisi gedung kuliah dengan prosentase $68,5 \%$

4. Biaya Pendidikan $54,2 \%$

5. Keringan biaya $53,7 \%$

6. Pengaruh Keluarga $53,2 \%$

7. Status Akreditasi $52,9 \%$

8. Kurikulum dengan prosentase $52,2 \%$

9. Dosen dengan prosentasi $49,8 \%$

10. Overseas stadium generale dengan prosentase $47,6 \%$

11. Keberhasilan alumni dengan prosentase $43,6 \%$

12. Karyawan dengan prosentase $39,6 \%$

13. Kemudahan mencari pekerja $39,3 \%$.

Berdasarkan hasil penelitian dapat dilihat bahwa 13 variabel independen terdapat 4 variabel yang kurang dari 50\% yaitu variable dosen, overseas studium generale, keberhasilan alumni, karyawan dan kemudahan mencari pekerjaan. Setelah itu dilakukan penentuan jumlah faktor baru atau pengelompokkan faktor dengan membandingkan nilai eigen, kemudian terbentuk 3 faktor baru sebanyak 3 faktor. Kontribusi terhadap daya tarik atau pengaruh terhadap pengambilan keputusan memilih Perguruan Tinggi sebesar 56,51\% yang merupakan penjumlahan prosentase 3 faktor baru yang diranking sebagai berikut :

a. Faktor akademik yang memberikan kontribusi paling besar dengan nilai total variance $34.072 \%$ dengan nilai eigen 4.584 . Hal ini menunjukkan bahwa faktor akademik merupakan faktor yang paling mempengaruhi sikap mahasiswa dan calon mahasiswa dalam mengambil keputusan memilih perguruan tinggi. Faktor akademik terdiri dari : keringanan biaya, biaya pendidikan, akreditasi, kurikulum, dosen, karyawan, kemudahan mencari pekerjaan.

b. Faktor sarana dan prasarana merupakan faktor kedua yang memberikan kontribusi dengan nilai variance $13.6 \%$ dengan nilai eigen 1.666 . Hal ini menunjukkan bahwa faktor sarana dan prasarana menjadi pertimbangan dan mempengaruhi sikap mahasiswa dalam mengambil keputusan memilih perguruan tinggi. Faktor sarana dan prasarana terdiri dari 3 variabel : kondisi gedung, kelengkapan fasilitas, kondisi lingkungan kampus.

c. Faktor pendukung memberikan kontribusi sebesar $8.54 \%$ dengan nilai eigen 1.032 . Hal ini menujukkan bahwa fakor pendukung memberikan pengaruh terhadap sikap calon 
mahasiswa dalam mengambil keputusan memilih perguruan tinggi. Faktor pendukung terdiri dari 2 variabel yaitu : Faktor overseas studium generale dan Faktor dukungan keluarga.

\section{Hasil Analisis Data Focus Group Discussion Dan Pembahasan}

Focus Group Discussion dilakukan terhadap perwakilan dari subjek penelitian dan merupakan perwakilan dari masing-masing Fakultas. Keseluruhan subjek berjumlah 11 orang yang terdiri dari 3 orang dari Fakitas IImu Kesehatan, 2 dari fakultas Farmasi, 3 dari fakultas Psikologi dan 3 dari Fakultas Teknik. Keseluruhan Subjek sudah pernah mengikuti studium generale yang dilakukan oleh Universitas Setia Budi.

Analisis data yang dilaksanakan oleh peneliti, memunculkan temuan-temuan yang sudah dikategorikan sebagai berikut:

- $\quad$ Faktor yang mendorong Subjek memilih Universitas Setia Budi

a. Pilihan dari orang tua

Ada beberapa alasan yang menentukan mengapa Subjek memilih Universita Setia Budi sebagai alternatif tempat Subjek menuntut ilmu. Salah satu faktornya adalah karena desakan dari orang tua dan pilihan dari orang tua.

b. Minat pada program studi yang ditawarkan oleh Universitas Setia Budi

Subjek menyatakan bahwa memilih Universitas Setia Budi sebagai tempat untuk kuliah dikarenakan tertarik dengan program studi yang ditawarkan oleh Universitas Setia Budi dan merupakan pilihannya sendiri.

c. Kesuksesan alumni di dunia kerja dan lamanya berdiri program studi

Subjek memilih Universitas setia Budi lebih karene pertimbangan jumlah alumni dan rekam jejak alumni pada program studi yang terbilang sukses serta pertimbangan yang lain karena lamanya berdiri atau program studi tersebut merupakan program studi terlama atu yang pertama kali diadakan oleh Universitas Setia budi

d. Promosi Universitas Setia Budi

Alternative memilih Universitas setia Budi disebabkan karena tertarik dengan penjelasan yang dilakukan oleh tim marketing Universitas Setia Budi,baik yang dilakukan oleh tim marketing yang ke sekolah-sekolah ataupun penjelasan yang dilakukan oleh dosen pada saat awal sebelum mereka mendaftar ke Universitas setia Budi.

\section{SIMPULAN}

\section{Kesimpulan}

Berdasarkan hasil penelitian dan pembahasan di atas dapat disimpulkan bahwa:

a. Terdapat 13 ranking faktor-faktor yang menentukan calon mahasiswa dan mahasiswa dalam memilih perguruan tinggi yaitu: 
b. Semula jumlah faktor yang mempengaruhi pengambilan keputusan ada 13 , setelah di analisis menjadi 3 faktor baru. Adapun faktor tersebut adalah
1) Faktor Akademik
2) Faktor Sarana dan Prasara
3) Faktor Pendukung.

c. Faktor akademik merupakan faktor yang paling dominan dengan jumlah varian yang mencapai $34.37 \%$ yang terdiri dari keringanan biaya, biaya pendidikan, status akreditasi, kurikulum, dosen, karyawan, dan kemudahan mencari pekerjaan.

d. Faktor Sarana dan Prasarana merupakan faktor kedua yang memberikan kontribusi dengan nilai variance 13.6 \% Faktor Sarana dan Prasarana terdiri dari 3 variabel, yaitu: kondisi gedung, kelengakapan fasilitas, dan kondisi lingkungan kampus.

e. Sementara faktor yang ketiga Faktor Penunjang terdiri dari 2 variabel, yaitu: overseas studium generale dan dukungan keluarga

\section{Saran}

Berdasarkan pada kesimpulan hasil penelitian yang telah dilakukan, maka terdapat saran yang dapat diberikan, antara lain:

a. Lebih meningkatkan kualitas dan kuantitas dalam aspek faktor akademik dan sarana prasarana. Karena kedua aspek tersebutlah yang lebih dominan dalam menentukan mahasiswa dan calon mahasiswa dalam memilih perguruan tinggi.

b. Melakukan evaluasi kembali kegiatan promosi dan program yang ditawarkan oleh Perguruan Tinggi agar dapat lebih menarik bagi calon mahasiswa. 


\section{DAFTAR PUSTAKA}

Amirullah dan Haris Budiono. (2010). Pengantar Manajemen. Cetakan kedua. Yogyakarta. Graha IImu.

Hadi, S. (2000). Statistik J ilid 2. Yogyakarta. Andi Offset.

Iranita. (2012). Analisis Faktor yang Mempengaruhi Pilihan Mahasiswa Fakultas Ekonomi Universitas Maritim Raja Ali Haji Dalam menciptakan Keunggulan kompetitif (competitive advantage). Jurnal ekonomi.Vol.3.No 2. Desember 2012.

Kotler, Philp and Amstrong. (2001). Principle of Marketing. Prentice-Hall International,Inc. A Division of Simon \& Scuster.Englewood Cliffs.

Mulyatiningsih, Endang. (2013). Metode Penelitian Terapan Bidang Pedidikan. Bandung. Alfabeta.

Padmono Yazid. (2001). Analiais faktor-faktor yang mempengaruhi Mahasiswa memilih kuliah di STIE Mahardika Surabaya. Tesis Program Pasca Sarjana. ABI. Surabaya.

Tampubolon. (2001). Perguruan Tinggi Bermutu. Jakarta. PT Gramedia Pustaka Indonesia. Tjiptono Fandi. (1998). Manajemen J asa. Yogyakarta: Penerbit Andi. 